\title{
Nietzsche as a Critic of Genealogical Debunking: Making Room for Naturalism without Subversion
}

\author{
MATTHIEU QUELOZ AND DAMIAN CUENI
}

Origin and critique of moral valuations. These two things do not coincide, as is facilely supposed (this belief is itself already the result of a moral judgment to the effect that "something that has come to be in such and such a way is worth little because its origin is immoral").

-Nietzsche, eKGWB 1885, 2[131]

This paper argues that Nietzsche is a critic of just the kind of genealogical debunking he is popularly associated with. We begin by showing that interpretations of Nietzsche which see him as engaging in genealogical debunking turn him into an advocate of nihilism, for on his own premises, any truthful genealogical inquiry into our values is going to uncover what most of his contemporaries deem objectionable origins and thus license global genealogical debunking. To escape nihilism and make room for naturalism without indiscriminate subversion, we then argue, Nietzsche targets the way of thinking about values that permits genealogical debunking: far from trying to subvert values simply by uncovering their origins, Nietzsche is actively criticising genealogical debunking thus understood. Finally, we draw out the consequences of our reading for Nietzsche's positive vision.

$\mathrm{R}$ UNNING counter to the popular view of Nietzsche as the archetypal genealogical debunker who criticises values by revealing their objectionable origins, this paper argues that even in On the Genealogy of Morality $(G M)$, there is an important respect in which Nietzsche is a critic of genealogical debunking. This contrasts with three common reactions to the book. The first is to embrace Nietzsche's project, understood as the attempt to criticise by revealing objectionable origins. ${ }^{1}$ The second is

1 See, e.g., Hoy (2009), who understands genealogy as "a philosophical method of analysis of how certain cognitive structures, moral categories, or social practices have 
to dismiss Nietzsche's project, so understood, because it falls prey to the genetic fallacy. ${ }^{2}$ The third is to dismiss the impression that Nietzsche is concerned with genealogical debunking at all: while it may look like Nietzsche is criticising by uncovering objectionable origins, he is really doing something else-evaluating our present values by their tendency to promote human flourishing, ${ }^{3}$ perhaps, or belabouring our sentiments through powerful rhetoric. ${ }^{4}$ In contrast to all three reactions, we want to vindicate both the impression that the GM is concerned with genealogical debunking and Nietzsche's project. We maintain that his project, correctly understood, is concerned with genealogical debunking, but in order to criticise it. Far from criticising values by revealing their objectionable origins, Nietzsche criticises those whose conceptions of values make those origins seem objectionable. ${ }^{5}$

come into being historically in ways that are contrary to the ordinary understanding of them" (223). Geuss (1994) reads the GM as an internal critique of Christian morality. Ridley (1998) takes a similar line, but views the critique as directed at a wider audience than just Christians. See also Owen (2003, 2007). Loeb (1995) reads it as a condemnation of base origins which hinges on Nietzsche's aristocratic values.

2 Koopman (2013, 20, 87) and Kim (1990). Solomon (1994), Hoy (1994), Conway (1994), and, in a different way, Finken (2012) are also critical of fallacious elements in Nietzsche's thought. See Queloz (2018) as well as Cueni and Queloz (Manuscript) for discussions of how genealogies can affect the space of reasons.

3 May (1999) reads it as an evaluation of values by the standard of life-enhancement; see also Guay (2006). Leiter (2002) reads it as a form of ideology critique designed to liberate great individuals from a stifling "herd morality."

4 Janaway (2007). Hatab (2008), Owen (2003, 2007, 2008), and Conway (1997) also stress the role of rhetoric as opposed to argument. Reginster $(2006,292 n 34)$ now denies that Nietzsche offers a new form of critique in the GM.

5 By foregrounding this particular aspect of Nietzsche's thought, we of course do not mean to deny that there is also a considerable extent to which Nietzsche is concerned to differentially evaluate and (in some cases) undermine the authority of particular values. But it is a standard view among commentators that it is not the uncovering of origins itself which does the undermining (see, e.g., Leiter 2002, 139-44). We mean to complement rather than to upend this standard view by highlighting the respect in which Nietzsche is in fact critical of such genealogical debunking. 
What leads Nietzsche to criticise genealogical debunking, on our view, is the need to overcome a problem that is prior to the differential evaluation of particular values: the problem of making room for a naturalism that is not indiscriminately subversive. This is a problem that arises on any reading of Nietzsche on which he seeks to understand values naturalistically without doing away with all values-a position which, for the purposes of this paper (Nietzsche's own usage of these terms is another matter), we might label naturalism without nihilism. ${ }^{6}$ The problem is compounded by Nietzsche's conviction that inquiry into origins will reveal even the most valued things to be not only merely natural at root, but also inextricably entangled with things considered bad or shameful: cruelty, suffering, blood, and horror. For if all things considered good come from things considered bad or shameful, how can we avoid the conclusion that any truthful naturalistic inquiry into the origins of our values is going to prove subversive and ultimately entrain nihilism? Before Nietzsche can engage in naturalistic explanation and

6 Our use of the term "nihilism" initially foregrounds what Bernard Reginster calls the "nihilism of disorientation" $(2006,8)$ : the complete lack of normative guidance entrained by the belief that nothing has value. He contrasts this with the "nihilism of despair" exemplified by Schopenhauer, a despair engendered by the belief that the highest values cannot be realised in this world. But on the account we go on to develop, both kinds of belief are but symptoms of something one can be committed to without being conscious of it or realising its nihilistic import: the ascetic conception of values. Viewing the ascetic conception of values as the source of nihilism accounts for the fact that, as Ken Gemes (Forthcoming) emphasises, Nietzsche also calls Christianity nihilistic (AC 18-20; eKGWB 1887, 11[367-73]; 1888, 17[4]) although Christians believe neither that nothing has value nor that they should despair of their values' realisation. But Christianity harbours an ascetic conception of values, and as we argue in $\$ 2$, it is because of this that Nietzsche thinks "morality will gradually perish" over the "next two centuries" (GM 3.27). For further discussion of what Nietzsche means by "nihilism," see Reginster (2006, ch. 1), Gemes (2008, Forthcoming), and Huddleston (Forthcoming). As for our understanding of Nietzsche's naturalism, it follows Kail (2009): we take Nietzsche to advocate a non-reductive, explanatory naturalism which combines a substantive commitment to the idea that humans are part of nature with a methodological commitment to rejecting a priori routes to knowledge. See also Queloz (2017). 
evaluate or rank our values according to their tendency to promote life, therefore, he needs to make room for naturalism without indiscriminate subversion.

Nietzsche sometimes (e.g., GM 2.7) sounds as if one simply has to be cut from same cloth as him to cheerfully accept what his contemporaries consider subversive origins. ${ }^{7}$ This can seem like mere chest-thumping on Nietzsche's part, or like an expression of his idiosyncratic values. But our guiding idea is that Nietzsche in fact offers a cogent and plausible argument to the effect that not just he, but anyone has reason to avoid the kind of susceptibility that renders naturalistic genealogical inquiry invariably subversive, and that what makes room for naturalism without subversion is not a particular set of values, but a different way of thinking about values.

On our reading, the nihilism-engendering residue of the enchanted world which renders genealogical explanations of values indiscriminately subversive is an ascetic conception of values as something peculiarly pure-pure of any contingent determination by such things as luck, human interests, or animal urges. In the kind of world Nietzsche takes us to live in, anyone has reason not to be as susceptible to genealogical debunking as this conception of values makes one. But as the current popularity of genealogical debunking arguments brings home, it is by no means clear that this is a conception of values we have outgrown. ${ }^{8}$ In Ethics and the Limits of Philosophy, for example, Bernard Williams feels the need to reiterate Nietzsche's critique of this "deeply rooted and still powerful misconception" (Williams 2011, 218) which insists

7 See Janaway (2017a, 2017b).

8 We have in mind the debates over whether beliefs can be debunked by showing that one's acceptance of them is orthogonal to their truth. See, e.g., Srinivasan (2015), Mogensen (2016), and DiPaolo and Simpson (2016). Although space constraints prohibit elaboration, we take the argument we ascribe to Nietzsche to be directly relevant to the contemporary debate. 
on "abstracting the moral consciousness from other kinds of emotional reaction or social influence" $(2011,216)$, conceives of moral value as lying beyond contingency and luck, "beyond any empirical determination" $(2011,217)$, and starkly contrasts such purity with the natural, emotional, and social forces pervading human life. This, we agree with Maudemarie Clark, is precisely "Nietzsche's ultimate problem with morality" $(2015,61)$ : that it expresses a conception of values as something that must be "separated out from the normal 'muck' of human life" (Clark 2015, 60). ${ }^{9}$

Accordingly, it is a less demanding conception of values that Nietzsche recommends on our reading. This is the conception of values that forms the final stage in the process of emancipation from an enchanted view of the world initiated by the "Death of God," i.e. the fact that "belief in God [... ] has become unbelievable" (GS 343). Once one goes far enough in accepting the Death of God, the origins of one's values, formerly perceived as destabilising, cease to be destabilising. Although Nietzsche himself does not put it this way, the point is best introduced in terms of a schematic depiction of a thought process that leads one through three stages of atheism. Stage one atheists react to the Death of God simply by subtracting certain metaphysical beliefs from the set of their beliefs while retaining their Christian moral values largely unchanged. Stage two atheists realise the deeper ramifications of the Death of God: without these metaphysical assumptions, the sorts of origins necessary for values to be authoritative cease to be available, and upon reflection, all values are seen to be susceptible to genealogical debunking. The correct inference to draw from the Death of God is thus that nothing has value-nihilism. Stage three atheists go one step

9 The present paper can be seen as developing the Williamsian line of interpretation indicated by Clark at the very end of her "On the Rejection of Morality: Bernard Williams's Debt to Nietzsche" (2015). 
further: they realise that the commitments licensing the inference from the Death of God to nihilism still express a metaphysical perspective on values. By relinquishing these commitments, stage three atheists free themselves from the corrosive grip of indiscriminate genealogical debunking and become able to affirm at least some of their values in the face of their origins.

Our argument in this paper falls into three parts. In $\S 1$, we argue that given Nietzsche's own premises, reading him as a genealogical debunker turns him into an advocate of nihilism, for any truthful genealogical inquiry into our values is going to uncover what most of his contemporaries deem objectionable origins-local will turn into global debunking, subverting our values across the board. To escape this threat of nihilism, we argue in $\$ 2$, Nietzsche targets genealogical debunking itself. The GM criticises a particular way of thinking about values, because that is what renders any evaluative outlook susceptible to dissolve into nihilism. In $\S 3$, we draw out the consequences of our reading for Nietzsche's positive vision.

\section{From Local to Global Genealogical Debunking}

Any reading of the GM is going to be guided by assumptions about Nietzsche's convictions and aims. Two such assumptions in the recent literature have been the following: (a) Nietzsche aims to offer naturalistic explanations of how values might have arisen out of the rest of nature without metaphysical interference; (b) Nietzsche is engaged in a rationally articulated critique of certain values, but he is not a nihilist who denies that anything has value. These assumptions are widely 
made and have been extensively argued for, so we will take them on board without rehearsing the arguments. ${ }^{10}$

Given these assumptions, a natural way to approach the GM is to look for a link between those two aspects of the book-to identify a sense in which naturalistic genealogical explanation undermines its object without leaving us with no values at all. But if one locates the critical force in the genealogical explanation itself, this sits rather uneasily with two further assumptions that can safely be made about Nietzsche: (c) Nietzsche believes that what is now evaluated-as-bad, such as cruelty, suffering, blood, and horror, is pervasive and something that one is nearly bound to come across once one inquires deeply enough into the origins of things that are evaluated-as-good; ${ }^{11}$ (d) he does not take origins to be capable of subversion by themselves. Let us examine each assumption.

(c) Awareness of the Pervasiveness of Suffering, Cruelty, Blood, and Horror: Nietzsche repeatedly voices a strong awareness of the fact that inquiry into the origins of what most of his contemporaries regard as "good" things will reveal them to be inextricably entangled with things that these same contemporaries regard as "bad," such as suffering, cruelty, blood, and horror:

reason, seriousness, mastery over the affects, this entire gloomy matter called reflection, all these prerogatives and showpieces of man: how dearly they have been paid for! how much blood and horror there is at the base of all "good things"! (GM 2.3)

An example of what Nietzsche might have in mind is the role of slavery in facilitating the birth of philosophical reflection. ${ }^{12}$ This and

${ }^{10}$ See Clark (1998), Leiter (2002), Janaway (2007), and Owen $(2007,2008)$ for comprehensive overviews.

${ }^{11}$ How exactly "origins" is to be understood will be addressed in the next section.

12 See Engels $(1987,168)$ and Williams (1993, 111-17). 
comparable passages (GM 3.9; eKGWB 1873, 29[172]; $E H$ "Untimely" 1; UM 2.1; D 49) lead Williams to note Nietzsche's "hypersensitivity to suffering" $(2012,143)$ and refusal to forget that suffering was necessary to achieving things that are now greatly valued. "All good things were once bad things" (GM 3.9), Nietzsche writes, and as Williams argues, this is one of Nietzsche's "fundamental tenets" $(2012,143)$, which, before it becomes a principle of interpretation in the hermeneutics of suspicion, presents itself to Nietzsche first and foremost as a fact. But we need to ask: what kind of fact is this? Does it express Nietzsche's own value commitments, or does it describe the relation between the value commitments of his contemporaries and the world? "Good" and "bad" for whom?

In GM 2.7, Nietzsche makes it very clear that in highlighting the pervasiveness of suffering, cruelty, blood, and horror, his intention is not to give grist to the "mills of life-weariness" of those he calls "the pessimists," who take suffering, cruelty, blood, and horror to be "bad" or "shameful" and thus to encourage life-denial. On the contrary, Nietzsche emphasises that the fact that such origins are perceived as "shameful" is the result of fairly recent cultural developments; his thoughts, he says,

are meant expressly to show that back then, when humanity was not yet ashamed of its cruelty, life on earth was more lighthearted than it is now that there are pessimists. The darkening of the heavens over man has always increased proportionally as man has grown ashamed of man. (GM 2.7)

It is a central idea in the $G M$, then, that what one perceives as "bad" or "shameful" origins—as pudenda origo (eKGWB 1885, 2[189])—is a function of one's evaluative commitments. While Nietzsche's contemporaries tend to perceive suffering, cruelty, blood, and horror as always bad or shameful, we also find in history the "reverse judgement" of 
those things as a "seductive lure to life."13 Nietzsche's claim that all good things come from or were once bad things should therefore not be heard as voicing Nietzsche's own evaluations, but rather as describing how the findings of truthful genealogical inquiry will appear to his contemporaries. When Nietzsche speaks of bad or shameful origins, he does not mean that they are bad or shameful in his eyes. We can mark this distinction between Nietzsche's endorsement of evaluations and his description of how the findings of genealogy will be evaluated by others thus: the point is not that they are bad or shameful, but that they are evaluated-as-bad-or-shameful, where this does not carry an evaluative commitment on Nietzsche's part. "All good things were once bad things" should be taken to mean: all things-now-evaluated-as-good were once things-now-evaluated-as-bad.

This may appear to strengthen the connection between (a) and (b), between naturalism and critique-not only is Nietzsche engaged in naturalistic explanations, he is also committed to such explanations looking fairly awful to his contemporaries: in the kind of world we live in, they are bound to reveal what will be perceived as "tainted" origins. But as we shall now see, Nietzsche's own conclusion is rather that uncovering such origins does not necessarily yield a critique.

(d) Origins in Themselves Cannot Subvert: Nietzsche repeatedly denies that something's having such-and-such origins ipso facto constitutes a ground for its indictment. Two years before the publication of the GM, he writes: "inquiry into the origin of our evaluations [...] is in no way identical with a critique of them" (eKGWB 1885, 2[189]). And in Book Five of The Gay Science, which appeared in the same year as the GM, he points out:

${ }^{13}$ See Janaway (2017a, 2017b). 
The mistake of the more subtle among [the historians of morality] is that they uncover and criticize the possibly foolish opinions of a people about their morality [...] and then think they have criticized the morality itself. [...] A morality could even have grown out of an error, and the realization of this fact would not so much as touch the problem of its value. (GS 345)

Origins are not incriminating in themselves (though some may mistakenly regard them to be so incriminating). What criticism Nietzsche offers of certain values hinges on their practical value as forces promoting the "enjoyment," "ennobling," "knowledge," and "development" of life (eKGWB 1886, 7[6]):

One could have proven ever so unflattering things about the origins of moral valuations: now that these forces are here, they can be used and have their value as forces. Just as a regime [Herrschaft] can originate in deceit and violence: its value lies in the fact that it is a regime.-Unless all the force of moral valuations were dependent on the legitimacy of its origins or more generally on a certain belief about their origins: in which case the force of the belief in the value would be lost if the mistake were discovered. (eKGWB 1884, 26[161])

On Nietzsche's view of things, according to which there is blood and horror at the basis of all things-now-evaluated-as-good, the question is not whether our values have origins evaluated-as-shameful, but whether we can live with the blood and horror. Far from animating his own critique, the subversive inference from origins to critique is part of what Nietzsche criticises:

Origin and critique of moral valuations. These two things do not coincide, as is facilely supposed (this belief is itself already the result of a moral judgment to the effect that "something that has come to be in such and such a way is worth little because its origin is immoral"). (eKGWB 1885, 2[131])

The origins that genealogical inquiry will tend to reveal are subversive only in conjunction with a further belief licensing the inference from 
origin to condemnation. This further belief is itself an ethical attitude, a second-order commitment to a certain way of thinking about values which can be put into question.

We can now see that readings on which Nietzsche takes origins to be in themselves properly capable of subversion face two problems. The first is that the scope of the critique is too broad. Given (c), all values would be undermined, which results in a nihilism violating (b). The second problem is that this would have Nietzsche commit the genetic fallacy, which is implausible in light of the four passages where Nietzsche rejects the idea that origins are subversive in themselves-it conflicts with (d).

This has led some to argue that while it may look like Nietzsche is deriving critique from explanation, he is really doing something less argumentative, such as attempting to alter our affects through powerful rhetoric (Janaway 2007). But this reaction conflicts with the assumption expressed in (b), that Nietzsche is presenting a rationally articulated critique.

Insofar as we want to hold on to the idea that there is a genealogical argument in the GM that does not target values tout court and avoids the genetic fallacy, one might argue that it takes the form of a narrower, internal critique - that Nietzsche is pinpointing contradictions within the evaluative commitments of the genealogy's addressees. This cashes out the thought that what origins are perceived as shameful is a function of one's outlook. Hence, genealogy can have subversive effects if the addressee's values claim authority for themselves in terms which the revelation of their true origins can undermine. Such internal readings can take several forms. Nietzsche might be viewed as deriving subversive conclusions about values from their 
(1) shameful historical origins: values $V$ historically arose out of motives perceived as shameful, such as hatred, ressentiment, and cruelty;

(2) shameful psychological origins: values $V$ now are psychologically rooted in and expressions of motives perceived as shameful, such as hatred, ressentiment, and cruelty; ${ }^{14}$

(3) functional origins: values $V$ originate as functional responses to basic needs, as tools for the satisfaction of further ends and ultimately of the will to power,;

(4) contingent origins: values $V$ are the product of various historical contingencies which fail to justify them against possible rivals-they are not inevitable or definitively desirable, but rationally contingent, ${ }^{16,17}$

All four forms of internal critique exhibit what is perceived as "higher" as originating in what is perceived as "lower." This argumentative structure is a form of local genealogical debunking:

Local Genealogical Debunking:

P1 Genealogical explanation of certain values $V$ reveals them to have origins $O$.

P2 Values $V$ claim authority for themselves in terms that are incompatible with their having origins $O$.

14 See, e.g., Geuss (1981), Reginster (1997).

15 See Richardson (2004) and Guay (2006).

${ }^{16}$ Here our argument connects with debates over whether beliefs can be debunked by showing that one's acceptance of them is orthogonal to their truth. Exploring this connection would require more space than we can give it here, but our argument can profitably be read with these debates in mind. See Srinivasan (2015), Mogensen (2016), and DiPaolo and Simpson (2016).

17 See Nehamas (1985, ch. 4). 
P3 If values $V$ claim authority for themselves in terms that are incompatible with their having origins $O$, and they in fact have origins $O$, then values $V$ should be called into question.

C1 Genealogical explanation shows that values $V$ should be called into question.

Readings along the lines of (1)-(4) take Nietzsche to show that certain-notably Christian-values have origins that are incompatible with the way Christianity understands itself and claims authority for itself, so that by Christianity's own lights, we should give it up.

But the problem with these readings is that they fail to contain the full subversive force of genealogical inquiry and thus run afoul of the fact that Nietzsche does not endorse remaining in nihilism. This is because the commitments on which the subversive force hinges are not specific to Christianity. This is obscured by talk of internal contradictions within Christianity. But the commitments on which local genealogical debunking hinges are not first-order commitments to specifically Christian values, but much broader second-order commitments about values: commitments specifying what origins bona fide values can properly possess. On reading (1), the relevant second-order commitment is that higher values have similarly high historical origins. On reading (2), it is that our present values must be expressive of high-minded motives. On reading (3), it is that moral reasons for action are genuinely distinct from, and not derivative of, instrumental reasons for action. On reading (4), it is that morality is pure of contingency, luck, and forces beyond voluntary control.

This suggests that the relevant second-order commitment is nothing other than Nietzsche's recurrent concern-the ascetic conception of values enshrined in the ascetic ideal: 
Ascetic Conception of Values (ACV): the highly valued must have higher origins; it must be pure, free of any connection with contingency, animal urges, human needs, self-interest, or power struggles.

In Beyond Good and Evil (BGE), the companion piece to the GM, Nietzsche discusses the ACV under the heading of "the metaphysicians' basic faith, the faith in the opposition of values" (BGE 2). ${ }^{18}$ This is the conviction that "[t]hings of the highest value must have another, separate origin of their own,- - they cannot be derived from this ephemeral, seductive, deceptive, lowly world, from this mad chaos of confusion and desire" (BGE 2)—what Clark calls "the normal 'muck' of human life" $(2015,60)$. To be truly valuable, the higher must itself have higher origins (BGE 230). It must not have grown out of the merely natural, and a fortiori not out of what is perceived as shameful. On Nietzsche's view, it is to provide appropriately pure origins that philosophers developed the realm of forms, the mind of God, or the noumenal world-all of them served as timeless homes to higher things, relative to which the lower world of "life, nature, and history" (GS 344) could be demoted to the status of a mere appearance (TI "Reason" 1 ). Instead of trying to explain how the higher might have emerged from the normal muck of things, "metaphysical philosophy has hitherto surmounted this difficulty by denying that the one originates in the other" (HAH 1). This "type of valuation," Nietzsche says of philosophers, "lies behind all their logical procedures" (BGE 2). It is "just their way of showing respect: the highest should not grow out of the lowest, it should not grow at all [... ]. It is an objection for something to come from something else, it casts doubt on its value" (TI "Reason" 4).

The key idea here is that in treating the revelation of a value's shameful origins as debunking it, we are undertaking a particular kind of second-order

${ }^{18}$ Clark $(1990,177)$ also argues that the faith in the opposition of values finds its way into the GM under the heading of the ascetic ideal. 
value commitment. In Nietzsche's terms, the coincidence of genealogy and critique is "itself already the result of a moral judgment to the effect that 'something that has come to be in such and such a way is worth little because its origin is immoral'" (eKGWB 1885, 2[131]). To undertake this second-order value commitment is to endorse (i) the inference from something's having a high value to its having high origins, and (ii) its contrapositive, the inference from its failing to have high origins (by having merely natural origins or even origins perceived as shameful) to its failing to have a high value. For one who endorses this pattern of reasoning, any connection of the higher with the normal muck of things contaminates the purity of the higher. A value's claim on us will be vindicated only if the value possesses a suitably pure pedigree; should a value be found to have origins that are perceived as lowly or shameful, its authority will be undermined. It will be unmasked as a mere illusion of value.

But in a world in which all things-now-evaluated-as-good come from things-now-evaluated-as-bad-or-shameful, the ACV endangers values across the board - not only those we live by, but also any foreseeable alternatives. This is a threat which those stuck in stage one atheism have yet to realise:

The event [the Death of God] is far too great, too distant, too remote from the multitude's capacity for comprehension even for the tidings of it to be thought of as having arrived as yet. Much less may one suppose that many people know as yet what this event really means-and how much must collapse now that this faith has been undermined because it was built upon this faith, propped up by it, grown into it: for example, the whole of our European morality. (GS 343)

Nietzsche, recognising that his contemporaries-like George Eliot (TI "Untimely" 5)—remain stage one atheists who accept the Death of God while holding on to Christian values, nevertheless considers the transition to stage two inevitable in the long run: combined with the 
conviction that genealogy will unearth natural origins and a large dose of blood and horror, the idea that the higher must remain pure of any association with such things inexorably entrains the conclusion that all first-order value commitments must be abandoned-it leads to global genealogical debunking:

\section{Global Genealogical Debunking:}

P1 Genealogy is bound to reveal our values to have origins $O$.

P2 All our values claim authority for themselves in terms that are incompatible with their having origins $O$.

P3 If all our values claim authority for themselves in terms that are incompatible with their having origins $O$, and they in fact have origins $O$, then all our values should be called into question.

C1 Genealogy is bound to show that all our values should be called into question.

Attempts to narrow the scope of Nietzsche's critique by interpreting it as internal fail, because Nietzsche presents these values as problematic according to a standard, the ACV, that is far more general. This subverts values across the board, depriving us not only of Christian values, but also of alternatives.

\section{Nietzsche's Real Target: The Ascetic Conception of Values}

Starting out from the question of how to derive critique from genealogical explanation, we ended up with the question of how genealogical explanation can fail to be critical. What renders Christian values susceptible to genealogical debunking is not in fact specific to them, but turns out to be a broader commitment endangering our values across the board: the ACV. On this conception, our values resist being understood in naturalistic terms. The only way to sustain first-order value 
commitments is to foster ignorance of their true origins with myths, illusions and lies. But here a further idea comes into play, namely the commitment to truthfulness which both Nietzsche and the outlook he examines share in some form. ${ }^{19}$ Truthfulness fuels a concern to eschew myths, illusions, and lies. It encourages reflection and demands that one render one's situation transparent to oneself through various forms of inquiry, including genealogical inquiry.

The resulting combination of (i) a first-order commitment to truthfulness, (ii) a world in which everything has a tainted and contingent history, and (iii) a second-order commitment to the ACV is unstable. Because of (i), we are led to move beyond comforting myths and to inquire into the real origins of our values; because of (ii), these origins will turn out to be what is deemed lowly; and because of (iii), this finding will have a destabilising effect. This issues in a situation in which we can neither go on believing in the revelation stories and origin myths in terms of which our values claim authority for themselves, nor go on respecting their claim on us in light of what we know about their actual origins.

Our aim in this section is to show how, in the GM, Nietzsche proposes to get out of this bind by rejecting (iii), the $\mathrm{ACV}$, to make room for a truthful naturalism that is not subversive. Nietzsche's hope is that, by engaging us in genealogical reflection, he can impress upon us that something is wrong with the ACV.

The uneasy combination of (i), (ii), and (iii), Nietzsche thinks, is the characteristic predicament of modernity. ${ }^{20}$ One is driven to abandon comforting myths and illusions, but finds little solace in the truths

${ }^{19}$ For the claim that truthfulness is part of the ascetic ideal, see GM 3.24, 27. For the claim that it is among Nietzsche's own commitments, see GM 1.1; AC 50; eKGWB $1886,5[71]$.

${ }^{20} E H$ "Beyond" 2; Williams (2000). 
replacing them. One "forbids oneself every kind of clandestine access to afterworlds and false divinities-but cannot endure this world though one does not want to deny it" (eKGWB 1887, 11[99]). This process of abandonment without replacement entrains the dissolution of one's entire evaluative outlook:

This antagonism - not to esteem what we know, and not to be allowed any longer to esteem the lies we should like to tell ourselves-results in a process of dissolution. (eKGWB 1886, 5[71])

This process of dissolution issues in nihilism, understood as the view that nothing has any value or meaning (eKGWB 1885, 2[127]). The truthful disenchantment of the world is not only "to a high degree ascetic," but also "to a still higher degree nihilistic": it drains the world of value and meaning until, like an "isolated arctic traveller," one is left with nothing but lifeless "winter landscapes": "Here there is snow, here life has become silent; the last crowings heard here are 'To what end?,' 'In vain!, 'Nada!'- here nothing more prospers or grows [... ]" (GM 3.26). It is in this sense that nihilism is the "necessary consequence of hitherto existing valuations," and "the danger of dangers" (eKGWB $1885,2[100])$. When viewed truthfully through the ACV, the world seems to leave no room for values.

The question is which path out of this nihilism-engendering triad Nietzsche advocates. There has been much discussion of Nietzsche's attitude towards (i), the commitment to truthfulness and its relation to illusion and art-but while he criticises forms of truthfulness which encourage the pursuit of truth at the expense of life, he is not usually taken to give up on truthfulness altogether. ${ }^{21}$ (i) thus remains in place, and whether (ii) obtains is largely not up to us. This leaves the question

${ }^{21}$ Anderson (2005), Gemes (1992, 2006), Harper (2015), Jenkins (2012, 2016), Owen (2003, 2007), Reginster (2013), Schacht (2013). 
whether we can overcome (iii), the ACV. We argue that this is the path Nietzsche recommends.

Nietzsche's thought is that the nihilist does not go far enough in recognising contingency. Nihilism stems from the idea that purity from contingency is what we would really like to have, because that is what makes the recognition that the world does not offer this kind of purity look like a disappointment. Against this, Nietzsche points out that the recognition that the world is more contingent than the ACV can allow is a step away from one's values, but not yet from an ascetic conception of them; there is a further step to be taken, and it is only then that we abandon the ascetic ideal, of which the ACV is the most tenacious element: it is what generates the very idea that something is lacking.

This is the conclusion reached by Nietzsche after spending the third treatise of the GM inquiring into the underlying meaning of the ascetic ideal. In the final section, he declares: "Precisely this is what the ascetic ideal means: that something was lacking, that an enormous void surrounded man" (GM 3.28). To fully abandon the ascetic ideal is to abandon this idea as well- to adopt a perspective from which the world's being more of a muck and mire than the ACV can allow is no longer experienced as a form of privation. If we take the leap into the void, it is seen not to be a void at all.

Nietzsche thus concludes that nihilism is a consequence of a particularly well-concealed asceticism-it is a counterfactual asceticism, just as it is counterfactual religiosity to conclude that if God does not exist, everything is permitted. ${ }^{22}$ To endorse this inference is to think that, were it not the case that everything was permitted, this would have to be because there was a God-which is still a religious idea. By the same token, it is still a form of asceticism to conclude that if the sort of

$\overline{22}$ See Williams's critique of "counterfactual scientism" $(2006,187)$. 
purity demanded by the ACV is not available because all values have originated in a natural world pervaded by suffering, then nothing has value. To think that the origins available on a naturalised conception of the world leave no room for values is to remain committed to the ascetic ideal: it is to hold on to an ascetic conception of what kind of world values require to gain a foothold. This is why the ascetic ideal eventually expresses itself in a will to nothingness. Its will to truth leads from the disenchantment of the world via a demanding conception of what counts as something - in the sense of something valuable - to the conclusion that we are left with nothing. It involves the idea that if anything were to have value, it would have to do so on the terms of the ascetic conception, and this is still an ascetic idea-one we must relinquish in order to perceive values that emerged out of the normal muck of things as genuine values.

Nietzsche's fundamental problem with the outlook of his contemporaries, then, is that it is prone to dissolve into nihilism due to the ascetic ideal, which combines an injunction to be truthful with the ACV. This combination issues in dissolution, because it makes it increasingly clear that the kind of purity demanded by the ACV is unavailable while blinding one to available alternatives. Hence Nietzsche's conclusion that the ascetic ideal is "the true doom in the history of European health" (GM 3.21).

Throughout his work from 1878 onwards, but under a variety of names, Nietzsche rejects the ACV and the reasoning it licenses, calling it a "mistake in reasoning" (HAH 1; see also D 49; GS 344; BGE 2; TI "Reason" 4, 5). ${ }^{23} \mathrm{He}$ encourages us to "doubt right here at the threshold, where it is needed most" (BGE 2). Genealogies are indeed subversive by the ascetic's standards, but while the ascetic takes this as a reason to

${ }^{23}$ A more fine-grained analysis than we have room for here might of course bring into focus various differences between the ideas we lump together as the ACV. 
give up the objects of the genealogies, Nietzsche takes it as a reason to give up the standard. He is thus a critic of genealogical debunking in the following sense:

Critique of Genealogical Debunking:

P1 Our values claim authority for themselves in terms that include a second-order commitment to the idea that bona fide values must not have origins of the kind perceived as lowly or shameful.

P2 On a naturalistic view of the world on which it is pervaded by blood and horror, all values will turn out to have origins of the kind perceived as lowly or shameful, thus permitting Global Genealogical Debunking.

P3 If our values claim authority for themselves in terms that permit Global Genealogical Debunking, then either all our values should be called into question, which issues in nihilism, or the commitment permitting Global Genealogical Debunking should be abandoned.

P4 Nihilism should be avoided at all costs.

C1 Therefore, the commitment to the idea that bona fide values must not have origins of the kind perceived as lowly or shameful should be abandoned.

The text standardly treated as the prime instance of genealogical debunking thus turns out to be part of a critique of genealogical debunking. Nietzsche is evaluating, not just our values, but even the ways in which we think about our values according to whether they are life-enhancing.

If there is this deeper critique afoot in the GM, one might wonder why so much of the GM describes the origins of particular first-order values. Our reading accounts for this by maintaining that there are not one but two kinds of critique at work in the GM, a first-order critique of values and a second-order critique of the way we think 
about values. The presence of one does not exclude the presence of the other-on the contrary, our claim is that the first-order critique, which has been the focus of commentators, presupposes and only makes sense against the background of the second-order critique. To adherents of the $\mathrm{ACV}$, any naturalistic explanation will seem to blacken its object. The difference between natural origins suggesting that a value promotes life and natural origins suggesting that it is harmful to life can be but a difference between two shades of black. It is only once we have relinquished the ACV that there is room for naturalistic explanation to be anything other than subversive, and that genuine reevaluation becomes possible.

But if the first-order critique presupposes the success of the secondorder critique, why does Nietzsche not proceed in reverse order, making room for naturalism without subversion before giving us his naturalistic explanations? A possible answer is that there is a performative and therapeutic rationale for proceeding in this fashion: it allows the firstorder critique to contribute to the second-order critique. By confronting his readers with a series of rhetorically charged vignettes and strong images depicting the lowly origins of Christian morality, Nietzsche puts pressure on the second-order commitment that the higher must not have emerged from the lower, thereby driving stage one atheists among his readers towards stage two. Although he himself does not ultimately endorse this sort of genealogical debunking, he can nevertheless exploit it for therapeutic purposes, exacerbating the destabilising tendencies of the ACV and precipitating a crisis of nihilism. ${ }^{24}$ On this reading, the relevant question is not whether our values in fact have precisely the origins Nietzsche depicts them as having. It is whether we think about

${ }^{24}$ Here we are indebted to Ken Gemes and Alexander Prescott-Couch. 
our values in terms that render them susceptible to subversion through the confrontation with origins of that kind.

Then, however, Nietzsche's second-order critique of the ACV urges the reader to move on to stage three, to shake off the expectations that fuelled genealogical debunking and to turn a critical eye on such wholesale genealogical debunking itself. Nietzsche's strategy is thus two-pronged: stage one atheists will be moved towards stage two by his genealogical stories, and stage two atheist will be moved towards stage three by his attack on the $\mathrm{ACV}{ }^{25}$ Ideally, one comes out of reading the $G M$ as a stage three atheist, holding second-order commitments that no longer license global genealogical debunking. One is then able to contemplate the possibility of one's values having the origins Nietzsche attributes to them in the GM without feeling one's commitment to these values to be compromised. One no longer experiences the lack of higher origins as a lack. One can in principle be confident in one's values even if they have lowly origins, much as, in Foucault's words, a "real science is able to accept even the shameful, dirty stories of its beginning" (1988, 15).

Indeed, reading Nietzsche's GM, stage three atheists would have trouble identifying the critical import of the genealogical stories. Arguably, time has shown that it is possible to emancipate ourselves from the ACV while retaining secular descendants of Christian values, and the trouble that contemporary readers have in seeing a non-fallacious critical import in Nietzsche's GM is just an expression of this fact. ${ }^{26}$

25 We are indebted to Ken Gemes for this way of putting the point.

26 That this ability for affirmation in the face of lowly origins cannot be taken for granted is poignantly brought out by the developments of Nietzsche's own day. Fritz Stern, in The Politics of Cultural Despair (1961), retraces the rise of the nineteenth-century Kulturkritiker or "Germanic critics" through the lens of a (notably early) sympathetic reading of Nietzsche. Stern argues that the Death of God and Darwin's theory of evolution were felt by many to drain the world of all values, and that a form of cultural despair was spreading in Europe (1961, 282-84). This led to the rise of the "Germanic 
Yet if naturalistic genealogies do not necessarily blacken their objects once one has abandoned the ACV, this allows them to play a different and subtler role in first-order critiques of values. Abandoning the $\mathrm{ACV}$ opens up a contrast range within which first-order critiques of values can, through more complex inferential paths than ACV-fuelled genealogical debunking, shed more or less flattering light on their object. ${ }^{27}$ Some genealogical explanations may, for instance, still be subversive by revealing the dysfunctionality of certain values. Values might turn out to be harmful by being repressive of our drives and injurious to our health; or by being insufficiently tailored to different types; or by constraining individual potential. But a genealogical explanation might equally prove vindicatory by highlighting the functionality of a value in any of these respects. Abandoning the ACV is thus a necessary-though not a sufficient-condition for naturalistic explanation not to be subversive, and Nietzsche is to be credited with perceiving this more clearly than his fellow naturalists. He points the way to naturalism without subversion.

critics" - people like Paul de Lagarde, Julius Langbehn, and Arthur Moeller van den Bruck-who, in an attempt to compensate for these losses, mythologised their cultural past to conjure up a fiction of German unity which developed a fateful influence in interwar Germany. Moeller van den Bruck, author of a book entitled The Third Reich, was an avid reader of Nietzsche and claimed him as an ally. But our analysis shows that Nietzsche is precisely the opposite. Both Nietzsche and the Germanic critics diagnosed tensions between how they understood their values and how they understood the world. But whereas the Germanic critics sought to react to the tension by re-idealising the world and their cultural history, Nietzsche attacked what created the tension in the first place.

27 See Cueni and Queloz (Manuscript) as well as Queloz (2017, 2018b, 2019, Forthcoming$a, b, c)$ for characterisations of some of those inferential paths. 


\section{Nietzsche's Vision:}

\section{Reflective Stability and the Pessimism of Strength}

Nietzsche thus sees the ACV as forcing a choice upon us: either we deceive ourselves about the world's true shape by idealising it with myths and illusions, or we see it for what it is and embrace nihilism. His way out of this bind, we have argued, is to reject the ACV. This reading of what Nietzsche opposes offers some indication of what he advocates instead. In this final section, we draw out the consequences of our reading for Nietzsche's positive vision.

If they are to escape the choice between untruthfulness and nihilism, healthy individuals are going to need an outlook that is stable under reflection. They are going to have to satisfy three conditions: (i) living truthfully; (ii) negating, or at least not endorsing, the ACV; (iii) having the psychological strength required to bear the truth about their outlook-to affirm it in the face of its true history. (i) is clear enough, so let us focus on (ii) and (iii).

In the Untimely Meditations (UM 2.1), Nietzsche describes how uncovering origins could be life-denying by alienating one from what one values; but in his later work, Nietzsche takes a further step, exploring the thought that what effect genealogy has on our values is a function of whether we take their authority to depend on their having certain origins. This leads Nietzsche to the conclusion that achieving a lifeaffirming outlook - an outlook that enables one to know life for what it is and still say "yes" to it-must involve one's coming to think and live by ideas that are stable under reflection, including reflection about where they come from and what their coming to be ours involved. That an evaluative outlook should be stable under truthful reflection is necessary if the holders of the outlook are to live truthfully without being driven into nihilism. 
As we saw, an important threat to this reflective stability is the ACV licensing the inference from origins to subversion. But as Nietzsche points out, the inference that "something that has come to be in such and such a way is worth little because its origin is immoral" itself involves a "moral judgement" (eKGWB 1885, 2[131]), and a moral judgement, for Nietzsche, is not a logical truth, but an interpretation, an Auslegung. ${ }^{28}$ Given a conception of values that lacked this particular interpretation and was at least in this respect non-ascetic, one would in principle be in a position to affirm values with natural and not altogether suffering-free origins. Hence requirement (ii) on achieving a life-affirming outlook: that one should have a non-ascetic conception of values.

Merely conceiving of values differently is not yet enough, however, to ensure that one will be able to affirm one's values when confronted with the origins that Nietzsche expects them to have. One also needs the psychological strength to bear whatever it is that inquiry into the history of our values might bring to light. This is requirement (iii), which is not a matter of principles or how we think of things, but a matter of strength of character. Unlike principles, such strength comes in degrees. The measure of one's strength will be how much truth about one's values one can incorporate into one's view of them while still affirming them. ${ }^{29}$ For Nietzsche, such truth is bound to involve a great deal of "harsh, ugly, unpleasant" (GM 1.1) truth. It will reveal the history of our values to involve suffering, for instance. But for Nietzsche, the problem is not purposeful suffering, which one endures for a reason, but senseless suffering, incurred as a result of bad luck, uncertainty, or sudden downturns (GM 2.7, 3.28). The real problem is

28 See $e$ KGWB 1885, 2[90]; BGE 187; TI "Morality" 5.

${ }^{29}$ In the GM, Nietzsche talks about the ability to digest the past (3.16), the strength to endure the truth about humankind and to bear a true biography (3.19-20). In $E H$, he notes that he takes the real standard of value to be how much truth a spirit dares and endures $(P, 3)$. 
the contingency of suffering. This is why Nietzsche defines "evil" as "chance, uncertainty, and the sudden" (eKGWB 1887, 10[21]). Fear of the consequences of these contingent forces is what generates the need either to give contingency the form of necessity by finding reasons for suffering or to demote the contingent realm of life, nature, and history to the rank of mere appearance. In its Schopenhauerian form, the pessimistic awareness of this state of things leads to the negation of life, the "death-wish" (eKGWB 1885, 2[100]). Yet in the form advocated by Nietzsche, that same pessimistic awareness issues in the affirmation of life. The former might be labelled the pessimism of weakness; the latter Nietzsche himself calls the pessimism of strength. ${ }^{30}$ He introduces it in the 1886 preface to the Birth of Tragedy (BT "Self-Criticism" 1) and expands on it in his notebooks: "Let us dwell a moment," he writes, "on this symptom of the highest culture-I call it the pessimism of strength" (eKGWB 1887,10[21]). It is the state in which mankind fearlessly accepts contingency-in which it no longer feels the need to rationalise the world or to deny its reality (eKGWB 1887, 10[21]). On the very grounds that formerly motivated life-denial, mankind manages to affirm life: "the sense of security and belief in law and calculability enter consciousness in the form of satiety and disgust - while the delight in chance, the uncertain and sudden becomes titillating" (eKGWB 1887, 10[21]). ${ }^{31}$ To exhibit pessimism of strength with relation to our values and their history is to balance awareness of their contingency with

30 On the affirmation of life, see Reginster (2006). On Nietzsche's relation to Schopenhauer, see Janaway (1998). On the pessimism of strength, see Soll (1988), Owen (2007, 18), and Williams (2012; 2014, ch. 37).

31 There is a puzzle in Nietzsche scholarship about why Nietzsche says that one should affirm life on the grounds that formerly motivated life-denial (Came 2013, 210). If one takes suffering to be what motivates denial, this generates the sadistic ideal that one should affirm life because of suffering. Our reading, on the other hand, yields the claim that one should affirm life because of the titillating delight one takes in chance, uncertainty, and the sudden. 
their unwavering affirmation. It is to treat the values we actually find, with the origins they actually have, as genuine values. This, as Bernard Williams emphasises in one of his more Nietzschean passages, is

... [not] a picture that is a product of despair, a mere second-best for a world in which the criteria of true objectivity and ethical truth-seeking have proved hard to find. To recognise how we are placed in this respect is, if anything, an affirmation of strength. $(1995,148)$

One consequence of this reading is that we can sensibly raise the question whether we can retain secular descendants of Christian values-provided they help us to live and do not hamper flourishing-if we give up the ACV and can bear the truth about them. Prima facie, Nietzsche does not seem to think so: he argues in TI that "Christian morality [... ] stands or falls along with belief in God" ("Untimely" 5). Such passages may seem to constitute an obstacle to our reading. But the key is to recognise that there are two distinct ways of feeling one's attachment to one's values to be unthreatened by the Death of God: one may be an atheist stuck at stage one, who fails to see the ramifications of the Death of God; or one may be an atheist at stage three, who has thoroughly overcome the ascetic perspective on values. When Nietzsche castigates the likes of George Eliot, he is objecting to the failure of his contemporaries to recognise the instability of stage one atheism. But one should not conclude from this that Nietzsche advocates coming to rest at stage two. He also criticises people who remain at stage two, where the Death of God is acknowledged to lead to nihilism. For Nietzsche, this is "a way of remaining and staying stuck in precisely those Christian and ascetic moral perspectives in which one had renounced faith along with the faith in God" (GS 357). Nietzsche thus criticises both stage one and stage two atheists, but only to push through to stage three. 
A crucial contrast for Nietzsche, then, is between those who view the origins revealed by genealogical inquiry as a threat to their values and shun truthful genealogical inquiry, and those who feel capable of affirming their values in the face of these origins and embrace genealogical inquiry-between those who "like to put questions of origins and beginnings out of [their] mind," and those who display a "contrary inclination" (HAH 1). The same contrast reappears at the beginning of $B G E$, where Nietzsche says that "we must await the arrival of a new breed of philosophers, ones whose taste and inclination are somehow the reverse of those we have seen so far" (BGE 2). This new breed with reverse tastes, we have suggested, consists of individuals who have freed themselves of the ascetic perspective and display a pessimism of strength to the extent that they can discern and affirm things of value even in a world in which these turn out to have links to the normal muck of life. This, Nietzsche thinks, is what a disenchanted world in which everything is in some way tied up with contingency and suffering demands of us. And once we meet these demands, genealogical inquiry ceases to appear uniformly subversive. Then-and only then-the familiar Nietzschean project comes into view, of differentiating between values according to whether they have helped us to live.

\section{Conclusion}

For Nietzsche, genealogical debunking is in the first instance a problem. Because our values have traditionally been understood in terms that render them incompatible with the origins genealogy is likely to bring to light, genealogical inquiry must issue in nihilism. By contrast to "English genealogists" (GM P 4) in the vein of Hume, Darwin, and Rée, who optimistically assume that genealogical explanations will strengthen our confidence in our values by revealing their utility, Nietzsche's darker 
outlook leads him to recognise that there is a prior task for the naturalist: in a world in which all things-evaluated-as-good come from thingsevaluated-as-bad and values anyway resist naturalistic explanation, one first needs to make room for naturalism without subversion.

Such a reading combines two traditionally opposed views of Nietzsche, the postmodern view of him as concerned with the destabilising force of history, and the naturalist view of him as concerned with making sense of values in non-metaphysical terms. Nietzsche is concerned with the critical force of history, but as an obstacle to naturalistic selfunderstanding. The image of Nietzsche as a genealogical debunker has to be turned on its head.

This paper has focused on the idea that bringing into view the differences between values presupposes ridding oneself of second-order ideas that level out these differences. Nietzsche shows us that for the project of the piecemeal evaluation of values against the background of their history to come clearly into focus, we must first purge our conception of values of the last remnants of asceticism. But given that this project has yet to come clearly into focus, and given that debates over how values fit into the natural world rage on, there is a real question whether we have fully done so. ${ }^{32}$

32 Thanks to Ken Gemes, Andrew Huddleston, Chris Janaway, Alexander PrescottCouch, Scott Jenkins, John Skorupski, Hallvard Lillehammer, Richard Elliott, Chris Sykes, Johannes Niederhauser, and all the participants in the Nietzsche seminar at Birkbeck College, University of London. Thanks are also due to Johannes Steizinger, Rebekka Hufendiek, Jelscha Schmid, Markus Wild, Martin Kusch, Jan Müller, and Claudio Baldi for their comments on earlier versions of this paper. This work was supported by grant N ${ }^{\circ}$ P0BSP1_162025 of the Swiss National Science Foundation. 


\section{Bibliography}

eKGWB (2009-), Digital Critical Edition of the Complete Works and Letters, edited by Paolo D'Iorio, based on the critical text by G. Colli and M. Montinari, Berlin and New York: De Gruyter.

TL (1979), "On Truth and Lies in a Nonmoral Sense", in Philosophy and Truth: Selections from Nietzsche's Notebooks of the early 1870's, ed. and trans. by Daniel Breazeale, New Jersey and London: Humanities Press International, pp. 79-97.

HAH (1986a), Human, All Too Human, ed. by Richard Schacht, trans. by

R. J. Hollingdale, Cambridge: CUP.

WS (1986b), The Wanderer and His Shadow, in HAH, pp. 301-95.

D (1997), Daybreak: Thoughts on the Prejudices of Morality, ed. by Maudemarie Clark and Brian Leiter, trans. by R. J. Hollingdale, Cambridge: CUP.

UM (1997b), Untimely Meditations, ed. by Daniel Breazeale, trans. by R.

J. Hollingdale, Cambridge: CUP.

GM (1998), On the Genealogy of Morality, ed. by Maudemarie Clark, trans. by Maudemarie Clark and Alan J. Swensen, Indianapolis and Cambridge: Hackett.

BT (1999), The Birth of Tragedy, ed. by Raymond Geuss and Ronald Speirs, trans. by Ronald Speirs, Cambridge: Cambridge University Press. GS (2001), The Gay Science, ed. by Bernard Williams, trans. by Josefine

Nauckhoff and Adrian Del Caro, Cambridge: CUP. BGE (2002), Beyond Good and Evil, ed. by Rolf-Peter Horstmann and Judith Norman, trans. by Judith Norman, Cambridge: CUP. AC, TI (2005), The Anti-Christ, Ecce Homo, Twilight of the Idols, and Other Writings, ed. by Aaron Ridley and Judith Norman, trans. by Judith Norman, Cambridge: CUP. 
Anderson, Robert Lanier. 2005. "Nietzsche on Truth, Illusion, and Redemption." European Journal of Philosophy 13 (2): 185-225.

Came, Daniel. 2013. "The Themes of Affirmation and Illusion in the Birth of Tragedy and Beyond." In The Oxford Handbook of Nietzsche. Edited by John Richardson and Ken Gemes, 209-225. Oxford: Oxford University Press.

Clark, Maudemarie. 1990. Nietzsche on Truth and Philosophy. Cambridge: Cambridge University Press.

—. 1998. "Introduction." In On the Genealogy of Morality, vii-xxxv. Indianapolis and Cambridge: Hackett.

-. 2015. "On the Rejection of Morality: Bernard Williams's Debt to Nietzsche." In Nietzsche on Ethics and Politics, 41-61. Oxford and New York: Oxford University Press.

Conway, Daniel. 1994. "Genealogy and Critical Method." In Nietzsche, Genealogy, Morality. Edited by Richard Schacht, 317-333. Berkeley: University of California Press.

—. 1997. Nietzsche's On the Genealogy of Morals: A Reader's Guide. London: Continuum.

Cueni, Damian, and Matthieu Queloz. Manuscript. [Anonymised for peer review].

DiPaolo, Joshua, and Robert Mark Simpson. 2016. “Indoctrination anxiety and the etiology of belief." Synthese 193 (10): 3079-3098. 10.1007/s11229-015-0919-6.

Engels, Friedrich. 1987. "Anti-Dühring." In Marx/Engels Collected Works. Vol. 25, 5-312. New York: International Publishers.

Finken, Bryan. 2012. "Nietzsche versus the Genetic Fallacy." Journal of Nietzsche Studies 43 (2): 305-315.

Foucault, Michel. 1988. Politics. Philosophy. Culture. Interviews and Other Writings 1977-1984. Edited by L. D. Kritzman. London: Routledge. 
Gemes, Ken. 1992. “Nietzsche's Critique of Truth." Philosophy and Phenomenological Research 52 (1): 47-65.

-. 2006. "'We Remain of Necessity Strangers to Ourselves': The Key Message of Nietzsche's Genealogy." In Nietzsche's On the Genealogy of Morals: Critical Essays. Edited by Christa Davis Acampora, 191-208. Lanham: Rowman and Littlefield.

-. 2008. "Nihilism and the Affirmation of Life: A Review of and Dialogue with Bernard Reginster." European Journal of Philosophy 16 (3): 459-466. 10.1111/j.1468-0378.2008.00314.x.

—. 2013. "Life's Perspectives." In The Oxford Handbook of Nietzsche. Edited by Ken Gemes and John Richardson, 553-575. Oxford: Oxford University Press.

-. Forthcoming. "Nietzsche, Nihilism, and the Paradox of Affirmation." In Nietzsche on Morality and the Affirmation of Life. Edited by Daniel Came. Oxford: Oxford University Press.

Geuss, Raymond. 1981. The Idea of a Critical Theory: Habermas and the Frankfurt School. Cambridge: Cambridge University Press.

—. 1994. "Nietzsche and Genealogy." European Journal of Philosophy 2 (3): 274-292.

Guay, Robert. 2006. "The Philosophical Function of Genealogy." In A Companion to Nietzsche. Edited by Keith Ansell Pearson, 353-370. Blackwell.

Harper, Aaron. 2015. "Nietzsche's Thumbscrew: Honesty as Virtue and Value Standard." Journal of Nietzsche Studies 46 (3): 367-390.

Hatab, Laurence J. 2008. "Breaking the Contract Theory: The Individual and the Law in Nietzsche's Genealogy." In Nietzsche, Power and Politics: Rethinking Nietzsche's Legacy for Political Thought. Edited by Herman W. Siemens and Vasti Roodt, 169-190. Berlin and Boston: De Gruyter. 
Hoy, David Couzens. 1994. "Nietzsche, Hume, and the Genealogical Method." In Nietzsche, Genealogy, Morality: Essays on Nietzsche's On the Genealogy of Morals. Edited by Richard Schacht, 249-267. Berkeley: University of California Press.

- 2009. The Time of Our Lives: A Critical History of Temporality. Cambridge, MA: MIT Press.

Huddleston, Andrew. 2017. "Nietzsche on the Health of the Soul." Inquiry 60 (1-2): 135-164. 10.1080/0020174X.2016.1258147.

-. Forthcoming. "Nietzsche on Nihilism: A Unifying Thread." Philosophers' Imprint.

Janaway, Christopher. 1998. Schopenhauer as Nietzsche's Educator. Oxford: Oxford University Press.

—. 2007. Beyond Selflessness: Reading Nietzsche's Genealogy. Oxford: Oxford University Press.

—. 2017a. "Attitudes to Suffering: Parfit and Nietzsche." Inquiry 60 (1-2): 66-95. 10.1080/0020174X.2016.1251165.

—. 2017b. "On the Very Idea of 'Justifying Suffering'." Journal of Nietzsche Studies 48 (2): 152-170.

Jenkins, Scott. 2012. “Nietzsche's Questions Concerning the Will to Truth." Journal of the History of Philosophy 50 (2): 265-289.

-. 2016. "Truthfulness as Nietzsche's Highest Virtue." Journal of Value Inquiry 50 (1): 1-19.

Kail, Peter J. E. 2009. "Nietzsche and Hume: Naturalism and Explanation." The Journal of Nietzsche Studies 37: 5-22.

Kim, Chin-Tai. 1990. "A Critique of Genealogies." Metaphilosophy 21 (4): 391-404.

Koopman, Colin. 2013. Genealogy as Critique: Foucault and the Problems of Modernity. Bloomington and Indianapolis: Indiana University Press.

Leiter, Brian. 2002. Nietzsche on Morality. 2 ed. London: Routledge. 
Loeb, Paul S. 1995. "Is There a Genetic Fallacy in Nietzsche's Genealogy of Morals?" International Studies in Philosophy 27 (3): 125-141.

May, Simon. 1999. Nietzsche's Ethics and his War on 'Morality'. Oxford: Clarendon Press, Oxford University Press.

Mogensen, Andreas L. 2016. "Contingency Anxiety and the Epistemology of Disagreement." Pacific Philosophical Quarterly 97 (4): 590-611.

Nehamas, Alexander. 1985. Nietzsche: Life as Literature. Cambridge, MA: Harvard University Press.

Owen, David. 2003. "Nietzsche, Re-Evaluation and the Turn to Genealogy." European Journal of Philosophy 11 (3): 249-272.

—. 2007. Nietzsche's Genealogy of Morality. Stocksfield: Acumen.

—. 2008. "Nietzsche's Genealogy Revisited." Journal of Nietzsche Studies 35 (1): 141-154.

Queloz, Matthieu. 2017. “Nietzsche's Pragmatic Genealogy of Justice." British Journal for the History of Philosophy 25 (4): 727-749. 10.1080/09608788.2016.1266462.

- 2018a. "How Genealogies Can Affect the Space of Reasons." Synthese. 10.1007/s11229-018-1777-9.

—. 2018b. "Williams's Pragmatic Genealogy and Self-Effacing Functionality." Philosophers' Imprint 18 (17): 1-20. 2027/spo.3521354.0018.017.

—. 2019. "Genealogy and Knowledge-First Epistemology: A Mismatch?" The Philosophical Quarterly 69 (274): 100-120. 10.1093/pq/pqy041.

-. Forthcoming-a. "From Paradigm-Based Explanation to Pragmatic Genealogy." Mind. 10.1093/mind/fzy083.

—. Forthcoming-b. "Nietzsches affirmative Genealogien." Deutsche Zeitschrift für Philosophie.

-. Forthcoming-c. “Nietzsche's English Genealogy of Truthfulness." Archiv für Geschichte der Philosophie. 
Reginster, Bernard. 1997. "Nietzsche on Ressentiment and Valuation." Philosophy and Phenomenological Research 57 (2): 281-305. $10.2307 / 2953719$.

-. 2006. The Affirmation of Life: Nietzsche on Overcoming Nihilism. Cambridge, MA: Harvard University Press.

-. 2013. "Honesty and Curiosity in Nietzsche's Free Spirits." Journal of the History of Philosophy 51 (3): 441-463.

Richardson, John. 2004. Nietzsche's New Darwinism. New York: Oxford University Press.

Ridley, Aaron. 1998. Nietzsche's Conscience: Six Character Studies from the Genealogy. Ithaca, NY: Cornell University Press.

Schacht, Richard. 2013. "Nietzsche's Genealogy." In Oxford Handbook of Nietzsche. Edited by Ken Gemes and John Richardson, 363-387. Oxford: Oxford University Press.

Stern, Fritz. 1961. The Politics of Cultural Despair: A Study in the Rise of German Ideology. Berkeley: University of California Press.

Soll, Ivan. 1988. "Pessimism and the Tragic View of Life: Reconsiderations of Nietzsche's Birth of Tragedy." In Reading Nietzsche. Edited by Richard Solomon and Kathleen M. Higgins, 104-31. Oxford: Oxford University Press.

Solomon, Robert C. 1994. "One Hundred Years of Ressentiment: Nietzsche's Genealogy of Morality." In Nietzsche, Genealogy, Morality. Edited by Richard Schacht, 95-126. Berkeley: University of California Press.

Srinivasan, Amia. 2015. “The Archimedean Urge." Philosophical Perspectives 29 (1): 325-362.

Williams, Bernard. 1993. Shame and Necessity. Berkeley: University of California Press. 
—. 1995. "Saint-Just's Illusion." In Making Sense of Humanity and Other Philosophical Papers, 1982-1993, 135-150. Cambridge: Cambridge University Press.

—. 2000. "Naturalism and Genealogy." In Morality, Reflection, and Ideology. Edited by Edward Harcourt, 148-161. Oxford: Oxford University Press.

- 2006. "Philosophy as a Humanistic Discipline." In Philosophy as a Humanistic Discipline. Edited by Adrian W. Moore, 180-199. Princeton and Oxford: Princeton University Press.

-. 2011. Ethics and the Limits of Philosophy. Routledge Classics. London and New York: Routledge.

- 2012. "Nietzsche: The Gay Science." In Introductions to Nietzsche. Edited by Robert B. Pippin, 137-151. New York: Cambridge University Press.

—. 2014. Essays and Reviews 1959-2002. Edited by Michael Woods. Princeton: Princeton University Press. 